\title{
Spoilage potential of spore-forming bacteria from refrigerated raw milk
}

\section{Potencial deteriorante de bactérias formadoras de esporos do leite cru refrigerado}

\author{
José Carlos Ribeiro Júnior ${ }^{1 *}$; Ronaldo Tamanini²; André Luís Martinez de \\ Oliveira $^{3}$; Juliane Ribeiro'; ${ }^{2}$ Vanerli Beloti ${ }^{2}$
}

\begin{abstract}
Aerobic bacterial spores are an important group of microorganisms in raw milk. These microbes are thermoduric, whereas the vegetative forms are thermophilic, thermoduric and psychrotrophic and reduce the shelf life of pasteurized milk. In Brazil, there are a lack of studies on the load of aerobic spores in raw milk; thus, little is known about the spoilage activity of these organisms. The aim the present study was to quantify the aerobic spores in Brazilian refrigerated raw milk of dairy region of Castro, Paraná state, assess the potential proteolytic and/or lipolytic isolates and identify the microorganisms derived from the germination. Twenty milk samples were evaluated, and the aerobic spore count was performed after plating the samples following heat treatment at $80^{\circ} \mathrm{C}$ for $12 \mathrm{~min}$. The activity proteolytic and lipolytic isolates were evaluated through subculture on milk agar and tributyrin agar, respectively, and these microorganisms were identified using partial 16S rRNA gene sequences that were compared through GenBank. The aerobic spore counts ranged from 1 to $3.7 \log \mathrm{CFU} \cdot \mathrm{mL}^{-1}$, with a mean of $1.75( \pm$ $0.59) \log$ CFU. $\mathrm{mL}^{-1}$. After spore germination, 137 aerobic bacterial isolates were obtained, 40 of which (29.2\%) showed milk spoilage activity. Among these, 31 isolates (77.5\%) were proteolytic and lipolytic, seven isolates (17.5\%) were exclusively lipolytic and two isolates $(5 \%)$ were only proteolytic. Based on the 16S rRNA gene analysis, Bacillus licheniformis (55\%), Bacillus spp. (27.5\%), Paenibacillus spp. (7.5\%), Bacillus pumilus (5\%), Bacillus circulans (2.5\%) and Brevibacillus spp. (2.5\%) were identified. Studies of Brazilian raw milk microbiota have not yet described $B$. circulans which are frequently detected in milk from other countries. Among the 22 B. licheniformis isolates, 21 microbes $(95.5 \%)$ showed proteolytic and lipolytic activity, and one isolate (4.5\%) exhibited only proteolytic activity. The two $B$. pumilus isolates were proteolytic and lipolytic, whereas the $B$. circulans isolate was only lipolytic. Among the 11 Bacillus spp. isolates, eight isolates (72.7\%) were proteolytic and lipolytic, one isolate (9.1\%) was proteolytic and the other two isolates $(18.2 \%)$ were lipolytic. The three Paenibacillus spp. and Brevibacillus spp. isolates were primarily lipolytic. Therefore, to extend the shelf life of pasteurized milk, preventive measures must be adopted to reduce contamination with spores because one-third of these microorganisms exhibited proteolytic and/or lipolytic activity.
\end{abstract}

Key words: Bacillus. Lipolysis. Proteolysis. Spores. Shelf life.

1 Pós-Doutor em Ciência Animal, Professor da Universidade Federal do Tocantins, UFT, Araguaína, TO, Brasil. E-mail: ribeirojuniorjc@gmail.com

2 Drs. em Ciência Animal, Instituto Nacional de Ciência e Tecnologia para a Cadeia Produtiva do Leite, INCT/Cadeia do Leite, Londrina, PR, Brasil. E-mail: ronaldot@uel.br; julianeribeiro@outlook.com; vbeloti@uel.br

3 Prof. Departamento de Bioquímica e Biotecnologia, Universidade Estadual de Londrina, UEL, Londrina, PR, Brasil. E-mail: almoliva@gmail.com

* Author for correspondence 


\section{Resumo}

Esporos de bactérias aeróbias são um importante grupo de micro-organismos no leite cru. Esses microorganismos são termodúricos, e suas formas vegetativas são termofílicas, termodúricas e psicrotróficas e reduzem a vida útil do leite pasteurizado. No Brasil, não há estudos sobre os esporos aeróbios no leite cru, assim, pouco se sabe sobre o potencial deteriorante dessa microbiota no leite cru brasileiro. $\mathrm{O}$ objetivo do presente trabalho foi quantificar esporos aeróbios no leite cru refrigerado brasileiro, avaliar o seu potencial proteolítico e/ou lipolítico e identificar esses micro-organismos originários da germinação dos esporos. Foram avaliadas 20 amostras de leite cru refrigerado, nas quais foi realizada a contagem de esporos aeróbios após o tratamento térmico de $80^{\circ} \mathrm{C}$ por $12 \mathrm{~min}$. A atividade proteolítica e/ou lipolítica dos isolados foi avaliada após o repique das colônias em ágar leite e tributirina, respectivamente, e a identificação desses micro-organismos deteriorantes foi realizada pelo sequenciamento parcial do gene 16S rRNA e comparação com as sequencias depositadas no GenBank. As contagens de esporos aeróbios variaram de 1 a $3.7 \log$ CFU.mL $L^{-1}$, com média de $1.75( \pm 0.59) \log \mathrm{UFC} . \mathrm{mL}^{-1}$. Após a germinação dos esporos, foram obtidas 137 colônias, das quais 40 (29.2\%) apresentaram algum tipo de atividade deteriorante: 31 (77.5\%) isolados foram proteolíticos e lipolíticos, sete (17.5\%) foram exclusivamente lipolíticos e dois (5\%) foram apenas proteolíticos. Baseado nas sequencias do gene 16S rRNA, foram identificados Bacillus licheniformis (55\%), Bacillus spp. (27.5\%), Paenibacillus spp. (7.5\%), Bacillus pumilus (5\%), Bacillus circulans (2.5\%) e Brevibacillus spp. (2.5\%) entre os esporulados deteriorantes. Estudos preliminaries sobre a microbiota do leite brasileiro ainda não haviam descrito $B$. circulans e Paenibacillus, gêneros frequentemente descritos no leite de outros países. Entre os 22 B. licheniformis, $21(95.5 \%)$ cepas apresentaram atividade proteolítica e lipolítica e um (4.5\%) isolado apresentou apenas atividade proteolítica. As duas cepas de B. pumilus foram proteolíticas e lipolíticas, e a cepa de B. circulans foi apenas lipolítica. Entre os 11 Bacillus spp., oito (72.7\%) cepas foram proteolíticas e lipolíticas, uma (9.1\%) foi apenas proteolítica e as outras duas (18.2\%) foram apenas lipolíticas. Os três isolados de Paenibacillus spp. e as cepas de Brevibacillus spp. apresentaram somente atividade lipolítica. Dessa forma, para aumentar a vida útil do leite pasteurizado brasileiro, medidas preventivas devem ser adotadas para reduzir a contaminação do leite cru por micro-organismos esporulados, uma vez que um terço dessa microbiota apresenta potencial deteriorante do leite.

Palavras-chave: Bacillus. Lipólise. Proteólise. Vida útil.

\section{Introduction}

In Brazil, refrigerated raw milk has low microbiological quality (MATTOS et al., 2010; SILVA et al., 2011; BELOTI et al., 2012; RIBEIRO JÚNIOR et al., 2015), which results in a shelf life of less than 6 days for pasteurized milk. However, some Brazilian dairy regions produce milk with high microbiological quality, thus meeting the international quality standards (RIBEIRO JÚNIOR et al., 2015; 2018), and can lead to the potential production of long-life pasteurized milk that has a shelf life of up to 20 days. In this context, controlling the microbiota could shorten the shelf life of Brazilian pasteurized milk and ensure that the consumer is provided long-life pasteurized milk with improved nutritional quality.
The formation of bacterial spores, particularly those of Bacillus species (SCHELDEMAN et al., 2004; 2005), is typically observed in raw milk and represents a problem for the dairy industry because bacterial spores confer resistance to pasteurization (BUEHNER et al., 2014) and Ultra High Temperature (UHT) treatment (ESPEJO et al., 2014). Thus, pasteurized milk microorganisms group is comprise by these bacteria, thermoduric nonsporulated microorganisms and post-pasteurization contaminants (JAY, 2000). Spore formers also can multiply at refrigerated temperatures (HULL et al., 1992; RIBEIRO JÚNIOR et al., 2018) and might deteriorate the shelf life of pasteurized milk (SCHELDEMAN et al., 2004; RANIERI et al., 2012). 
Some spore-forming microorganisms multiply at higher temperatures and are therefore considered thermophilic (BURGESS et al., 2010; YUAN et al., 2012; GLEESON et al., 2013). These microorganisms are of fundamental importance to the dairy industry because they adhere to pasteurization plates, contaminate processed milk and resist the cleaning and sanitizing process.

In Brazil, therearefew studies of the contamination of refrigerated raw milk with bacterial spores; thus, little is known about the spoilage potential of this microbiota. Therefore, the aim the present study was to verify the aerobic spore-forming bacterial counts in refrigerated raw milk produced in the dairy region of Castro, state of Paraná, southern Brazil, and to evaluate the proteolytic and lipolytic potential of these microorganisms and genetically identify these microbiota, so that later studies can determine their origin and, consequently, measures that control the contamination of raw milk by sporulates.

\section{Material and Methods}

\section{Sampling Unit}

We evaluated 20 refrigerated raw milk samples produced in the municipalities of Castro $(n=14)$ and Arapoti $(n=6)$, the central region of the state of Paraná, southern Brazil. All samples selected for the study were obtained on different properties with an average daily production ranging 5,000-29,000 liters. All lactating animals of these properties were maintained in free stalls with sand bed or sawdust and fed corn silage, with concentrate commercial and mineral protein salt. The water was obtained from artesian wells, and milking was conducted in a closed circuit and one using a robot. Six properties used raw milk plate cooler before storage in bulk tanks. These properties were previously characterized by Ribeiro Júnior et al. (2015; 2017).

Subsequently, 500-mL samples of the refrigerated raw milk were aseptically collected from bulk tanks on farms from November 2013 to May 2014 and then transported under refrigeration to Animal Products Inspection Laboratory of State University Londrina for further analyses. The samples were evaluated for aerobic spore count within 4 hours of collection.

\section{Milk treatments and aerobic spore counts}

The aerobic spore count in the milk was performed according to the Standard Methods for the Examination of Dairy Products. Two hundred milliliters of each sample were subjected to $80{ }^{\circ} \mathrm{C}$ $( \pm 0.5) / 12 \mathrm{~min}$ to remove the bacterial vegetative forms and stimulate spore germination (FRANK; YOUSEF, 2004).

After the thermal treatment, the samples were serially diluted (up to $10^{-2}$ ) in saline $(0.85 \%)$ and peptone $(0.001 \%)$, followed by surface plating $(0.1$ $\mathrm{mL}$ ) in plate count agar (Oxoid Ltd., Basingstoke, Hampshire, UK) supplemented with $0.1 \%$ soluble starch (Synth ${ }^{\circledR}$, Diadema, São Paulo, Brazil). The plating was performed in duplicate for each dilution, and the plates were inverted and incubated for 48 hours at $32^{\circ} \mathrm{C}$.

\section{Spoilage potential and morphological identification} of isolates

Immediately after counting the colonies derived from the germination of the spores, all these bacteria were inoculated onto milk agar (Acumedia, Baltimore, USA) supplemented at a ratio of 9:1 with sterile $10 \%$ skim milk solution and onto tributyrin agar (Himedia, Mumbai, India) supplemented a ratio of 99:1 with tributyrin to verify the proteolytic (BEERENS; LUQUET, 1990) and lipolytic activity (HANTSIS-ZACHAROV; HALPERN， 2007), respectively.

The colonies of spore-forming bacteria that showed proteolytic and/or lipolytic activity were fixed using heat onto optical microscopy slides for morphological identification using Gram staining 
(TORTORA et al., 2013) and cultured in brain heart infusion broth (BHI) (Acumedia, Baltimore, USA) for 24 hours at $35^{\circ} \mathrm{C}$ for DNA extraction.

\section{DNA extraction and polymerase chain reaction}

The DNA was extracted from all proteolytic and/ or lipolytic bacteria isolated after spore germination according to Ribeiro Júnior et al. (2016a). For molecular analysis, the $16 \mathrm{~S}$ rRNA gene was partially amplified using the primers Y1f and Y3r (CHEN et al., 2000) in a thermocycler (Aeris ${ }^{\mathrm{TM}}$ Thermal Cycler, Esco ${ }^{\circledR}$ Micro Pte, Singapore) according to Young et al. (1991), incrementing the $2^{\circ} \mathrm{C}$ annealing temperature $\left(62^{\circ} \mathrm{C}\right)$ as previously described.

\section{Sequencing and sequence analysis}

The purification of the amplified DNA was performed using the PureLink ${ }^{\circledR}$ Quick Gel Extraction Kit (Life Technologies, Carlsbad, CA, USA) and quantified using the Qubit ${ }^{\circledR}$ BR dsDNA Assay Kit (Invitrogen, Carlsbad, CA, USA) according to the manufacturer's instructions.

The amplified rDNA was sequenced in both directions with primers $27 \mathrm{f}$ and 1492r (OSBORNE et al., 2005) using the commercial kit BigDye ${ }^{\circledR}$ Terminator v3.1 Cycle Sequencing Kit (Life Technologies, Carlsbad, CA, USA) according to the manufacturer's instructions, and the results were read using an automated sequencer based on the Sanger method (ABI 3500 Genetic Analyzer, Applied Biosystems, Carlsbad, CA, USA).

The chromatograms were analyzed using the platform "Electropherogram quality analysis" (http://asparagin.cenargen.embrapa.br/phph/) EMBRAPA Genetic Resources and Biotechnology. The quality of the sequences was analyzed using the Phred program. Subsequently, the consensus sequence was obtained using the CAP3 "Sequence Assembly Program" - (http://pbil.univ-lyon1.fr/ cap3.php) (HUANG; MADAN, 1999).
The generated consensus sequence was compared with the other sequences deposited in public databases (GenBank) using the BLAST 2.0 program (Basic Local Alignment Search Tool - http://www.ncbi.nlm.nih.gov/blast/Blast. cgi) developed by the National Center for Biotechnology Information (NCBI) for similarity search. Representative sequences of the identified species were deposited in GenBank.

The alignment of the nucleotide sequences with the sequences previously determined standard isolates was estimated using CLUSTAL W (version 1.4) using the MEGA 6 software (TAMURA et al., 2013). Phylogenetic analysis was conducted using the distance evolutionary model Tamura-Nei (TAMURA; NEI, 1993) and the neighbor-joining algorithm with bootstrap supporting for 1000 replicates.

\section{Results and Discussion}

The mean count of aerobic spores in the samples was $1.75 \log$ CFU.mL ${ }^{-1}$, with a range of 1.0 to 3.7 $\log$ CFU.mL ${ }^{-1}$.

One hundred thirty-seven pure isolates of sporeforming aerobic bacteria were isolated, of which 40 (29.2\%) showed milk spoilage activity. Among these, $31(77.5 \%)$ isolates were proteolytic and lipolytic, seven isolates $(17.5 \%)$ were exclusively lipolytic and two isolates $(5 \%)$ were only proteolytic. Gram staining revealed 40 colonies with the morphologies of Gram-positive bacilli.

The partial sequencing of the amplified $16 \mathrm{~S}$ rRNA gene identified 25 species of the 40 isolates through comparison with other sequences deposited in public databases (GenBank) using the BLAST 2.0 program. The genus level identification of the remaining 15 isolates are shown in Table 1. The identification at the species level was not possible due to the high genetic proximity of the 16S rRNA gene fragment with several species of the same genus. 
Table 1. The spoilage potential of spore-forming bacterial isolates isolated from 20 samples of Brazilian refrigerated raw milk.

\begin{tabular}{lcccccccc}
\hline \multirow{2}{*}{ Identification } & \multicolumn{2}{c}{ Total } & \multicolumn{2}{c}{ Proteolytic and lipolytic } & \multicolumn{2}{c}{ Proteolytic } & \multicolumn{2}{c}{ Lipolytic } \\
\cline { 2 - 9 } & $(n)$ & $(\%)$ & $(n)$ & $(\%)$ & $(n)$ & $(\%)$ & $(n)$ & $(\%)$ \\
\hline Bacillus licheniformis & 22 & 55 & 21 & 95,5 & 1 & 4,5 & & \\
\hline Bacillus spp. & 11 & 27,5 & 8 & 72,7 & 1 & 9,1 & 2 & 18,2 \\
\hline Paenibacillus spp. & 3 & 7,5 & & & & & 3 & 100 \\
\hline Bacillus pumilus & 2 & 5 & 2 & 100 & & & & 1 \\
\hline Bacillus circulans & 1 & 2,5 & & & & & 1 & 100 \\
\hline Brevibacillus spp. & 1 & 2,5 & & & & & 7 & 17,5 \\
\hline Total & 40 & 100 & 31 & 77,5 & 2 & 5 & & \\
\hline
\end{tabular}

A majority of the $B$. licheniformis isolates showed proteolytic and lipolytic activity and, unlike the results of American studies reporting the proteolytic activity of Paenibacillus spp. (HUCK et al., 2007; MARTIN et al., 2011), the isolates from these microorganisms obtained in the present study only showed lipase activity, as shown in Table 1.

After the alignment of the sequences, a phylogenetic tree (Figure 1) was generated, which demonstrated the cluster similarity of $B$. licheniformis isolates isolated (GenBank accession numbers KP713760 through KP713762) with different isolates of the same species deposited in the database and proximity with others species of spore-forming bacteria isolated from raw milk in several countries (KF879302, KF879293, and KJ622304).

The deposited sequences for $B$. pumilus (KP713763 and KP713764) were grouped with $B$. altitudinis (KC414717), B. aerophilus (KC414715) and B. safensis (JN699023), demonstrating the great similarity between Bacillus species that can interfere in clustering identification analyzes. B. pumilus was recently described for the first time in Brazilian raw milk and its vegetative form was described as thermoduric, proteolytic and psychrotrophic (RIBEIRO JÚNIOR et al., 2017).

The aerobic spore counts in the raw milk of the region studied were considered low compared with the results of Huck et al. (2007), showing averages of 4.69 and $4.03 \log$ CFU.mL $L^{-1}$ of sporeforming bacteria in the raw milk obtained from the cooling tanks of two industries in the state of New York (United States). In that same state, Martin et al. (2011) followed four dairy industries for a year and observed aerobic spore counts in raw milk ranging from 3.57 to $5.08 \log$ CFU.ml ${ }^{-1}$. Accordingly, Buehner et al. (2014) evaluated the aerobic spore counts of raw milk during the winter $\left(-9^{\circ} \mathrm{C}\right)$ and summer $\left(30^{\circ} \mathrm{C}\right)$ in the state of South Dakota, United States, and observed significant differences in the average scores of 2.06 and 1.08 $\log$ CFU.mL ${ }^{-1}$; higher spore counts were observed in winter and were associated with the increased adversity in the environmental temperature drop, thus favoring the sporulation of vegetative forms of these microorganisms.

Considering only the counts, therefore, it is expected that the refrigerated raw milk of the studied region presents microbiological quality compatible or better than the American milk, which when pasteurized has an average shelf life of 21 days. Therefore, the milk evaluated by the present work can be considered of high microbiological quality and high technological potential, considering only aerobic spore counts, mainly responsible for the compromise of the shelf life of the US pasteurized milk. 
Figure 1. Phylogenetic tree constructed using the neighbor-joining method based on alignment of $602 \mathrm{bp}$ of the 16S rDNA of spore-forming bacteria. The samples in the present study (isolates Lipoa/UEL, followed by the GenBank deposit numbers) were marked with diamond symbol and grouped in the same phylogenetic position as the recognized isolates of Bacillus licheniformis, Bacillus circulans, Bacillus pumilus, Brevibacillus and Paenibacillus (sequence number deposited in GenBank). The 16S rRNA sequence of Streptococcus pyogenes (isolate I-273) was used as an outgroup. The phylogenetic distance is indicated as 0.01 nucleotide substitutions

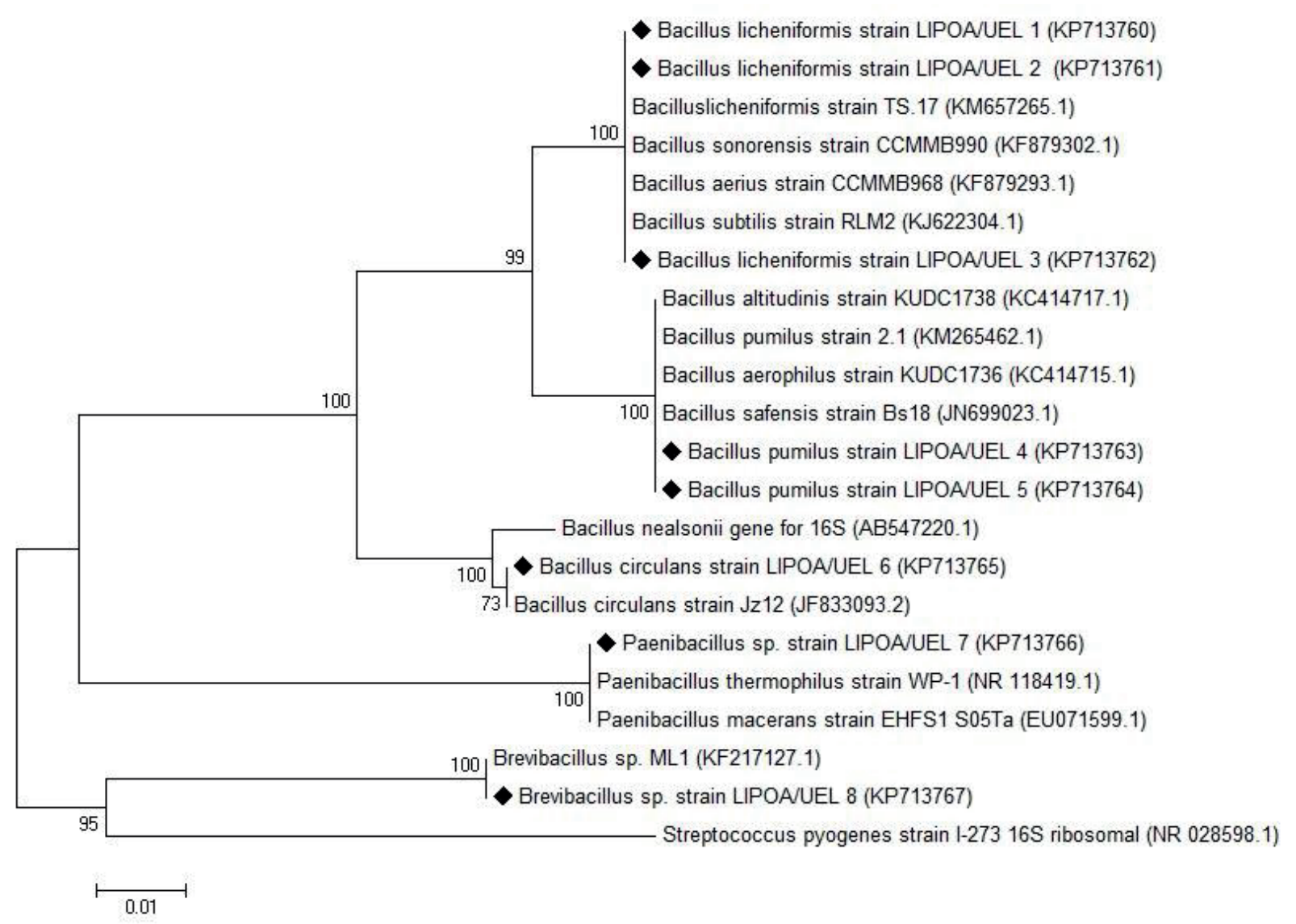

B. licheniformis is aerobic spore bacteria frequently isolated from raw milk in several countries, such as Belgium (SCHELDEMAN et al., 2005; COOREVITS et al., 2008), Uruguay (REGINENSI et al., 2011), China (YUAN et al., 2012) and the United States (BUEHNER et al., 2014), and the spores of these bacteria can be spread through air (TORTORA et al., 2013). These microorganisms multiply at temperatures from 15 to $55^{\circ} \mathrm{C}$ and in sodium chloride concentrations of up to $7 \%$, and endospores, which are present in the central region and multiplied at a $\mathrm{pH}$ of 5.5 to 8.5, produce casein hydrolases to reduce nitrate to nitrite (BURGESS et al., 2010).
Very similar, B. pumilus was isolated from milk in Belgium (COOREVITS et al., 2008), Uruguay (REGINENSI et al., 2011) and the United States (BUEHNER et al., 2014) and characterized as a producer of proteases that hydrolyze casein in the central position of the spore, with multiplication at temperatures of 5 to $55{ }^{\circ} \mathrm{C}$ in up to $7 \%$ of sodium chloride (BURGESS et al., 2010).

The lactase production in $B$. circulans has been previously described and used in biotechnological processes (BULTEMA et al., 2014), and cyclodextrin glycosyltransferase, which catalyzes the conversion of starch into cyclic or linear oligosaccharides, is 
an important industrial product for complexing nonpolar substances (COSTA et al., 2015). However, little is known about the lipase activity of these bacteria.

The microorganisms of the Paenibacillus genus have frequently been reported as a component of the spore microbiota of raw milk in the United States (SCHELDEMAN et al., 2004; HUCK et al., 2007; RANIERI et al., 2012.). This first report in Brazilian raw milk was previously published (RIBEIRO JÚNIOR et al., 2016b), for the team of this study.

The origin of the milk contaminated with Paenibacillus spp. is likely associated with the animal feed, and one of the sources of contamination is Bacillus sp. (GIFFEL et al., 2002). The germination of the spores of Paenibacillus spp. occurs during the shelf life of pasteurized milk, thereby initiating sensory changes that cause deterioration (SCHELDEMAN et al., 2005) and promote lipolysis and proteolysis. However, in the present study, only lipase activity was verified.

Huck et al. (2007) reported that in the United States, experimentally pasteurized raw milk stored for 14 days at $6^{\circ} \mathrm{C}$, presented microbiota predominantly composed by Paenibacillus spp. (83 of 88 isolates), which resulted in the germination of the spores of these microorganisms during the shelf life under cooling and in the deterioration of pasteurized milk. Martin et al. (2011) also showed the germination of Paenibacillus spp. spores in pasteurized milk after 14 days, and after 21 days, this microbiota primarily comprised Bacillus and Paenibacillus.

Vissers et al. (2007) estimated that among a contamination of $1,000 \mathrm{CFU}_{\mathrm{ml}}{ }^{-1}$ of spoilage microorganisms in milk, $33 \%$ of these microbes originate in the soil. Other studies have reported that milk can be contaminated with microorganisms sporulated from animal food, water, feces, ceilings and milking equipment (HULL et al., 1992; CHRISTIANSSON et al., 1999; TORP et al., 2001; GIFFEL et al., 2002). In the food animal group, corn silage submitted scores of 11.81 to $6.30 \log \mathrm{CFU} / \mathrm{g}$ of sporulated bacteria depending on the time of year (BUEHNER et al., 2014), and these bacteria were considered a major source of milk contamination, in addition to the production and storage conditions.

Borreani et al. (2013) evaluated these storage conditions for corn silage and reported that the aerobic spore counts might vary from 2.65 to 9.30 $\log \mathrm{CFU} / \mathrm{g}$ silage between the first and 14th day of exposure to air. These authors indicated that the Paenibacillus spp. population in this silage was $58.2 \%$ and $88.9 \%$ of these counts, respectively.

Thus, the implementation of preventive hygiene measures, such as contamination points, the avoidance of dust and animal feed into contact with the milkand the maintenance of all milking circuits and properly sealed storage units is necessary to reduce these microorganisms in milk.

\section{Acknowledgements}

We would like to thank the teams at the Animal Products Inspection Laboratory, the Molecular Biology Laboratory and Professor André Luis Martinez de Oliveira of the State University of Londrina.

\section{References}

BEERENS, H.; LUQUET, F. M. Guía practico para el análisis microbiológico de la leche y los productos lácteos. Zaragoza: Editorial Acríbia S.A., 1990. 141 p.

BELOTI, V.; RIBEIRO JÚNIOR, J. C.; TAMANINI, R.; SILVA, L. C. C. Impacto da implantação de boas práticas de higiene na ordenha sobre a qualidade microbiológica e físico-química do leite cru refrigerado. Revista do Instituto de Laticínios Cândido Tostes, Juiz de Fora, v. 388, n. 388, p. 5-10, 2012.

BORREANI, G.; DOLCI, P.; TABACCO, E.; COCOLIN, L. Aerobic deterioration stimulates outgrowth of sporeforming Paenibacillus in corn silage stored under oxygen-barrier or polyethylene films. Journal of Dairy Science, Champaign, v. 96, n. 8, p. 5206-5216, 2013. 
BUEHNER, K. P.; ANAND, S.; GARCIA, A. Prevalence of thermoduric bacteria and spores on 10 midwest dairy farms. Journal of Dairy Science, Champaign, v. 97, n. 11, p. 6777-6784, 2014.

BULTEMA, J. B.; KUIPERS, B. J. H.; DIJKHUIZEN, L. Biochemical characterization of mutants in the active site residues of the $\beta$-galactosidase enzyme of Bacillus circulans ATCC 31382. FEBS Open Bio, Oxford, v. 4, n. 1, p. 1015-1020, 2014.

BURGESS， S. A.; LINDSAY， D.; FLINT, S. H. Thermophilic bacilli and their importance in dairy processing. International Journal of Food Microbiology, Torino, v. 144, n. 2, p. 215-225, 2010.

CHEN, L. S.; FIGUEREDO, A.; PEDROSA, F. O.; HUNGRIA, M. Genetic characterization of soybean rhizobia in Paraguay. Applied and Environmental Microbiology, Washington, v. 66, n. 11, p. 5099-5103, 2000.

CHRISTIANSSON, A.; BERTILSSON, J.; SVENSSON, B. Bacillus cereus spores in raw milk: factors affecting the contamination of milk during the grazing period. Journal of Dairy Science, Champaign, v. 82, n. 2, p. 305314, 1999.

COOREVITS, A.; JONGHE, V.; VANDROEMME, J.; REEKMANS, R.; HEYRMAN, J.; MESSENS, W.; VOS, P.; HEYNDRICKX, M. Comparative analysis of the diversity of aerobic spore-forming bacteria in raw milk from organic and conventional dairy farms. Systematic and Applied Microbiology, Bremen, v. 31, n. 2, p. 126140, 2008.

COSTA, H.; GASTÓN, J. R.; LARA, J.; MARTINEZ, C. O.; MORIWAKI, C.; MATIOLI, G.; FERRAROTTI, S. A. Cyclodextrin glycosyltransferase production by free cells of Bacillus circulans DF 9R in batch fermentation and by immobilized cells in a semi-continuous process. Bioprocess and Biosystems Engineering, Switzerland, v. 38, n. 6, p. 39-47, 2015.

ESPEJO, G. G. A.; HERNANDEZ HERRERO, M. M.; JUAN, B.; TRUJILLO, A. J. Inactivation of Bacillus spores inoculated in milk by ultra high pressure homogenization. Food Microbiology, London, v. 44, n. 1, p. 204-210, 2014.

FRANK, J. F.; YOUSEF, A. E. Test for groups of microorganisms. In: WEHR, H. M.; FRANK, J. K. (Ed.). Standard methods for the examination of dairy products. $17^{\text {th }}$ ed. Washington: American Public Health Association, 2004. Chapter 8, Section 8.090 and 8.100, p. 239-242.

GIFFEL, M. C.; WAGENDORP, A.; HERREWEGH, A.; DRIEHUIS, F. Bacterial spores in silage and raw milk.
Antonie van Leeuwenhoek, Switzerland, v. 81, n. 14, p. 625-630, 2002.

GLEESON, D.; CONNELL, A.; JORDAN, K. Review of potential sources and control of thermoduric bacteria in bulk-tank milk. Irish Journal of Agricultural and Food Research, Dublin, v. 52, n. 2, p. 217-227, 2013.

HANTSIS-ZACHAROV, E.; HALPERN, M. Culturable psychrotrophic bacterial communities in raw milk and their proteolytic and lipolytic traits. Applied and Environmental Microbiology, Washington, v. 73, n. 22, p. 7162-7168, 2007.

HUANG, X.; MADAN, A. CAP3: A DNA sequence assembly program. Genome Research, Harbor, v. 9, n. 9, p. 868-877, 1999.

HUCK, J. R.; HAMMOND, B. H.; MURPHY, S. C.; WOODCOCK, N. H.; BOOR, K. J. Tracking spore-forming bacterial contaminants in milk fluid milk-processing systems. Journal of Dairy Science, Champaign, v. 90, n. 10, p. 4872-4883, 2007.

HULL, R. R.; TOYNE, S.; HAYNES, I. N.; LEHMANN, F. L. Thermoduric bacteria: a re-emerging problem in cheesemaking. Australian Journal of Dairy Technology, Sydney, v. 47, n. 1, p. 91-94, 1992.

JAY, J. M. Modern food microbiology. $6^{\text {th }}$ ed. New York: Chapman and Hall, 2000. 701 p.

MARTIN, N. H.; RANIERI, M. L.; MURPHY, S. S.; RALYEA, R. D.; WIEDMANN, M.; BOOR, K. J. Results from raw milk microbiological tests do not predict the shelf-life performance of commercially pasteurized fluid milk. Journal of Dairy Science, Champaign, v. 94, n. 3, p. 1211-1222, 2011.

MATTOS, M. R.; BELOTI, V.; TAMANINI, R.; MAGNANI, D. F.; NERO, L. A.; BARROS, M. A. F.; PIRES, E. M. F.; PAQUEREAU, B. P. D. Qualidade do leite cru produzido na região do agreste de Pernambuco, Brasil. Semina: Ciências Agrárias, Londrina, v. 31, n. 1, p. 173-182, 2010.

OSBORNE, C. A.; GALIC, M.; SANGWAN, P.; JANSSEN, P. H. PCR-generated artefact from 16S rRNA gene-specific primers. FEMS Microbiology Letters, Oxford, v. 248, n. 2, p. 183-187, 2005.

RANIERI, M. L.; IVY, R. A.; MITCHELL, W. R.; CALL, E.; MASIELLO, S. N.; WIEDMANN, M.; BOOR, K. J. Real-time PCR detection of Paenibacillus spp. in raw milk to predict shelf life performance of pasteurized fluid milk products. Applied and Environmental Microbiology, Washington, v. 78, n. 2, p. 5855-5863, 2012.

REGINENSI, S. M.; GONZÁLEZ, M. J.; OLIVERA, J. A.; SOSA, M.; JULIANO, P.; BERMÚDEZ, J. RAPD- 
based screening for spore-forming bacterial populations in Uruguayan commercial powdered milk. International Journal of Food Microbiology, Torino, v. 148, n. 1, p. 36-41, 2011.

RIBEIRO JÚNIOR, J. C.; BELOTI, V.; MASSI, F. P.; FUNGARO, M. H. P. Thermoduric psychrotrophic proteolytic microbiota from refrigerated raw milk. Semina: Ciências Agrárias, Londrina, v. 38, n. 1, p. $267-$ 272, 2017.

RIBEIRO JÚNIOR, J. C.; OLIVEIRA, A. M.; SILVA, F. D. G.; TAMANINI, R.; OLIVEIRA, A. L. M.; BELOTI, $\mathrm{V}$. The main spoilage-related psychrotrophic bacteria in refrigerated raw milk. Journal of Dairy Science, Champaign, v. 101, n. 1, p. 75-83, 2018.

RIBEIRO JÚNIOR, J. C.; TAMANINI, R.; SILVA, L. C. C.; BELOTI, V. Quality of milk produced by small and large dairy producers. Semina: Ciências Agrárias, Londrina, v. 36, n. 2, p. 883-888, 2015.

RIBEIRO JÚNIOR, J. C.; TAMANINI, R.; SOARES, B. F.; OLIVEIRA, A. M.; SILVA, F. G.; SILVA, F. F.; AUGUSTO, N. A.; BELOTI, V. Efficiency of boiling and four other methods for genomic DNA extraction of deteriorating spore-forming bacteria from milk. Semina: Ciências Agrárias, Londrina, v. 37, n. 5, p. 3069-3078, 2016 a.

RIBEIRO JÚNIOR, J. C.; ALCÂNTARA, B. K. D.; BELOTI, V. Spoilage potential of Paenibacillus spp. in Brazilian raw milk. Ciência Rural, Santa Maria, v. 46, n. 4, p. 637-640, 2016b.

SCHELDEMAN, P.; GOOSSENS, K.; RODRIGUEZDIAZ, M.; PIL, A.; GORIS, J.; HERMAN, L.; VOS, P.; LOGAN, N. A.; HEYNDRICKX, M. Paenibacillus lactis sp. nov., isolated from raw and heat-treated milk. International Journal of Systematic and Evolutionary Microbiology, Salamanca, v. 54, n. 3, p. 885-891, 2004.

SCHELDEMAN, P.; PIL, A.; HERMAN, L.; VOS, P.; HEYNDRICKX, M. Incidence and diversity of potentially highly heat-resistant spores isolated at dairy farms. Applied and Environmental Microbiology, Washington, v. 71, n. 3, p. 1480-1494, 2005.
SILVA, L. C. C.; BELOTI, V.; TAMANINI, R.; OVIDIO, L.; MATTOS, M. R.; ARRUDA, A. M. C. T.; PIRES, E. M. F. Rastreamento de fontes da contaminação microbiológica do leite cru durante a ordenha em propriedades leiteiras do Agreste Pernambucano. Semina: Ciências Agrárias, Londrina, v. 32, n. 1, p. 267276, 2011.

TAMURA, K.; NEI, M. Estimation of the number of nucleotide substitutions in the control region of mitochondrial DNA in humans and chimpanzees. Molecular Biology and Evolution, Torino, v. 10, n. 3, p. 512-526, 1993.

TAMURA, K.; STECHER, G.; PETERSON, D.; FILIPSKI, A.; KUMAR, S. MEGA6: molecular evolutionary genetics analysis version 6.0. Molecular Biology and Evolution, Torino, v. 30, n. 12, p. 27252729, 2013.

TORP, M.; HOLSTAD, G.; GRANUM, P. E. Bacillus cereus: feeds and feces as major contamination sources in milk on a dairy farm. Norsk Veterincertidsskrift, Berlim, v. 113, n. 2, p. 462-466, 2001.

TORTORA, G. J.; FUNKE, B. R.; CASE, C. L. Microbiology: an introduction. $11^{\text {th }}$ ed. Yorkshire: Pearson, 2013. 975 p.

VISSERS, M. M. M.; DRIEHUIS, F.; GIFFEL, M. T.; JONG, P.; LANKVELD, J. M. G. Concentrations of butyric acid bacteria spores in silage and relationships with aerobic deterioration. Journal of Dairy Science, Champaign, v. 90, n. 2, p. 928-936, 2007.

YOUNG, J. P.; DOWNER, H. L.; EARDLY, B. D. Phylogeny of the phototrophic rhizobium strain BTAi1 by polymerase chain reaction-based sequencing of a 16S rRNA gene segment. Journal of Bacteriology, Washington, v. 173, n. 7, p. 2271-2277, 1991.

YUAN, D. D.; LIU, G. C.; REN, D. Y.; ZHANG, D.; ZHAO, L.; KAN, C. P.; YANG, Y. Z.; MAA, W.; LI, Y.; ZHANG, L. B. A survey on occurrence of thermophilic bacilli in commercial milk powders in China. Food Control, Vurrey, v. 25, n. 2, p. 752-757, 2012. 
